\title{
Not a scientist: how politicians mistake, misrepresent, and utterly mangle science
}

Book

Reviewed by

Abstract

Keywords

DOI
LEVITAN, D. (2017). NOT A SCIENTIST: HOW POLITICIANS MISTAKE, MISREPRESENT, AND UTTERLY MANGLE SCIENCE.

NEW YORK, NY, U.S.A.: W. W. NORTON \& COMPANY

\section{Zachary Kizer}

Science permeates nearly every facet of human life and civilization. However, in an age of media oversaturation, it has been increasingly easier for pseudoscientific information to be disseminated among the masses, especially by those with a political agenda. In his book, Not a Scientist: How Politicians Mistake, Misrepresent, and Utterly Mangle Science, author Dave Levitan creates a guidebook for spotting and debunking unscientific ideas in the political sphere, a vital tool in the Information Age.

Public understanding of science and technology; Science and media; Science and policy-making

https://doi.org/10.22323/2.17010704

Science is a fundamental building block of human civilization. In spite of this, it is not always well understood by the general public, either as a specific process or a general concept. As a result, science is vulnerable to abuse and distortion, particularly for political purposes. Dave Levitan's Not a Scientist: How Politicians Mistake, Misrepresent, and Utterly Mangle Science, is a well-written and timely antidote to this trend, especially in the age of "fake news," where it has become increasingly more difficult to distinguish between objective truth and deceptive propaganda.

Levitan's book is a thorough and well-researched guidebook for debunking anti-scientific rhetoric. Each of the fifteen chapter focuses on one specific rhetorical move employed by politicians to distort scientific principles and accomplishments. Each technique is then applied to real-world examples of politicians employing it in a public forum, namely interviews or speeches. The book's structure allows for concise and detailed analysis; giving each topic the coverage it deserves without bogging down the readers with too much information, which is helpful for non-academic readers.

In his foreword, Levitan [2017] explains that the book makes no mention of Donald Trump, as it predates his election, but does make note of Trump's unique rhetorical 
technique: "The Firehose," meaning an endless stream of errors [p. xi]. In his introduction, Levitan [2017] traces the title's origin to a 1980 speech by Ronald Reagan, in which he said he was "not a scientist" but (incorrectly) stated that volcanoes create more pollution than humans [p. 1] In Chapter One, Levitan [2017] defines "The Oversimplification" as "strong, definitive claims" that ignore the nuances of a scientific topic [p. 11]. Chapter Two explains "The Cherry-Pick" as selectively pulling out information to suit one's agenda while ignoring the "larger body of evidence" [Levitan, 2017, p. 29]. Chapter Three, "The Butter-Up and Undercut," explains how politicians undermine scientific research under the guise of praise [Levitan, 2017, p. 46]. Chapter Four, "The Demonizer," describes a tactic that takes a "difficult and usually scary" concept and links it to an unrelated and unpopular politicized issue [Levitan, 2017, p. 60]. Chapter Five, "Blame the Blogger," discusses politicians citing information from dubious sources, under the assumption that the audience won't bother to fact check their statements [Levitan, 2017, p. 74]. In Chapter Six, the "Ridicule and Dismiss," Levitan [2017] explains how pundits make a complex topic sound so ludicrous that the audience dismisses it as absurd [p. 99].

In Chapter Seven, "The Literal Nitpick," Levitan [2017] explains how a focus on the "very specific definition of words used" is used to minimize fallout of incorrect statements [p. 112]. Chapter Eight, "The Credit Snatch," describes politicians claiming a scientific accomplishment happened under their watch, ignoring larger social processes that lead to such developments [p. 124-125]. In Chapter Nine, "The Certain Uncertainty," Levitan explains how pundits claim that fields of study without "utter, complete, 100 per cent proof" are invalid and thus shouldn't be pursued [Levitan, 2017, p. 139]. Chapter Ten, "The Blind-Eye to Follow-Up," explains how reliance on "outdated, improved-on or outright debunked" information can be used for political purposes [Levitan, 2017, p. 156]. In Chapter Eleven, "The Lost in Translation," Levitan [2017] explains that information can be distorted as it travels through the political grapevine [p. 175]. In Chapter Twelve, "The Straight-Up Fabrication," Levitan [2017] explains the nature of claims with no basis in science or reality whatsoever [p. 186]. Levitan [2017] concludes his book on "The Conspicuous Silence," in which politicians simply ignore major scientific concerns, thus implying they are inconsequential [p. 201]. The book ends with Levitan [2017] reminding the reader to always be on the lookout for bogus scientific claims.

Though this book is both of high quality and social importance, there are two issues that readers may see as omissions. First, in his counterattacks on politically charged pseudoscience, Levitan makes no reference to Creationism, a pseudoscience whose proponents often employ techniques very similar to those listed in this book. According to a 2010 Gallup poll, approximately thirty-eight percent of Americans believed that humans were created in their present form within the last ten thousand years, in line with the Biblical account of Creation [Althouse, 2015]. Though no longer accepted in the realm of mainstream scientific institutions, Creationism nonetheless has a strong political presence in American society, and thus its exclusion from this book is surprising.

Second, Levitan focuses almost exclusively on Republican and conservative politicians, with only casual references to the unscientific ideas promoted by Democratic and liberal pundits. While there is considerable evidence that 
right-wingers in general make more noise in terms of anti-science rhetoric that is no reason to ignore the potential intellectual faux pas of the Left. A 2011 survey found that forty-one percent of Democrats believe in Young Earth Creationism and eighty-one percent believed in global warming, compared to fifty-eight percent and forty-nine percent respectively for their Republican counterparts [Shermer, 2013]. While Republicans clearly hold the majority in both instances, that still leaves a significant proportion of Democrats who reject science in the exact same manner. In his introduction, Levitan [2017] claims that his focus on conservative anti-science is not a "partisan statement," which makes the lack of focus on its liberal counterpart even more puzzling [p. 7].

Overall, however, Levitan's Not a Scientist is a potent wake-up call on the lackluster state of American science education and serves as an excellent how-to guide to scholars for debunking rhetoric that butchers science for the sake of political expediency.

References

Author

\section{How to cite}

(C) The Author(s). This article is licensed under the terms of the Creative Commons Attribution - NonCommercial - NoDerivativeWorks 4.0 License.

ISSN 1824-2049. Published by SISSA Medialab. jcom.sissa.it
Althouse, M. T. (2015). 'Charting the Idealism of Intelligent Design: A Small-Scale Map of Local Advocacy'. Communication Quarterly 63 (4), pp. 444-462. https://doi.org/10.1080/01463373.2015.1058288.

Levitan, D. (2017). Not a scientist: How politicians mistake, misrepresent, and utterly mangle science. New York, NY, U.S.A.: W. W. Norton \& Company.

Shermer, M. (1st February 2013). 'The liberals' war on science: How politics distorts science on both sides of the spectrum'. Scientific American. URL: https://www. Sc ientificamerican.com/article/the-liberals-war-on-science/.

Zachary Kizer received his BA in Film \& Media Studies from Ball State University in 2015, and will be receiving his MA in Communication Studies from Ball State in May 2018. E-mail: zakkizer42@gmail.com.

Kizer, Z. (2018). 'Not a scientist: how politicians mistake, misrepresent, and utterly mangle science'. JCOM 17 (01), R04. https:/ / doi.org/10.22323/2.17010704. 